\title{
ANCA-associated Vasculitis: A Prothrombotic State Even in Remission?
}

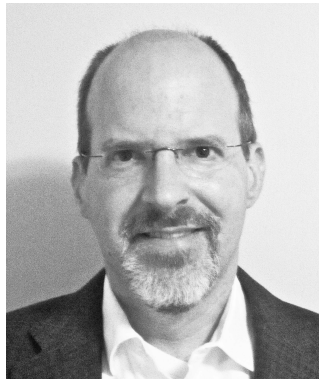

It is well established that active antineutrophil cytoplasmic antibody-associated vasculitis (AAV) - granulomatosis with polyangiitis (Wegener's; GPA) or microscopic polyangiitis - is associated with a very high risk of venous thromboembolic events (VTE): about 7 per 100 person-years ${ }^{1,2,3,4}$, compared to $0.15-0.31$ in the general population $^{5,6,7}$. Risk probably remains elevated, although to a much lower degree, during remission. Such risk has been calculated (1.0 per 100 person-years) in only 1 study ${ }^{4}$ and was not formally compared to the published data on healthy persons available at the time ${ }^{5}$; but dissection of data from the other studies of VTE in $\mathrm{AAV}^{1,2,3}$ and addition of data from new and very large cohorts of healthy persons support the statement that the relative risk of VTE during quiescent AAV is elevated, probably to about the same degree as in rheumatoid arthritis or inflammatory bowel disease $e^{6,7,8}$. The increased risk of VTE in AAV, regardless of disease activity, cannot be attributed to the known risk factors for $\mathrm{VTE}^{2,4,9}$.

It is on this background that Hilhorst, et al looked for evidence of hypercoagulability in patients with quiescent $\mathrm{AAV}^{10}$. At first glance, it might appear that investigating active AAV would be more fruitful, but since abnormalities related to leukocytes, endothelial cells, platelets, and coagulation proteins are all prominent in active $\mathrm{AAV}^{4,11,12,13,14}$, it is likely that multiple prothrombotic mechanisms are operating simultaneously. Thus, clinical remission provides an opportunity to identify prothrombotic abnormalities with the prospect of defining clear - and likely surprising - mechanisms.

Hilhorst, et al used the endogenous thrombin potential (ETP), a sensitive indicator of overall plasma coagulability ${ }^{15}$, as their primary measure. This type of assay has been used in only 1 previous study of patients with vasculitis, which reported very high thrombin generation in children with active vasculitis, particularly those with clinically apparent thrombosis, but mostly normal levels in children with inactive vasculitis ${ }^{12}$. In the study by Hilhorst, et al, ETP was clearly higher on average among patients than controls (although there was some overlap), in spite of the fact that levels of the anticoagulant proteins tissue factor pathway inhibitor, protein $\mathrm{C}$, and protein $\mathrm{S}$ were at least nominally higher among patients. The procoagulant protein factor VIII was also higher in patients than controls, leading the authors to propose that endothelial cell dysfunction is the source of the hypercoagulable state. This conclusion may be an overstatement, since the other major branch of thrombogenesis - platelet function - was not analyzed; but the core finding is unambiguous.

The question then arises: Were the patients truly in remission? On clinical grounds, several factors strongly challenge the notion that vasculitis was brewing within the cohort at the time of sampling: only 2/27 patients relapsed during followup, relapse-free patients were followed for at least 1 year, and median followup time was 5 years. Treatment status also argues that this cohort was in remission, and that findings cannot be attributed to artifacts of treatment: $8 / 27$ patients were untreated at the time of sampling, and their ETP appeared to be elevated to the same degree as in patients treated with prednisone or other immune-suppressive drugs. A more rigorous definition would include normal markers of inflammation; C-reactive protein (CRP) was normal in many patients in this study, but ETP was not analyzed relative to CRP and treatment status. One could argue that antineutrophil cytoplasmic antibody (ANCA) status should also be used to identify patients in remission with the greatest confidence, because ANCA - the only marker of ongoing autoimmunity in AAV - might lead to inflammation undetectable by other means, or cause direct or indirect injury to endothelial cells ${ }^{16,17}$. Again, most patients in this cohort were ANCA-negative at the time of sampling, but a specific group of untreated, ANCA-negative patients in longterm remission with normal CRP was not defined, and the number of such patients would have been no more than 8 and likely difficult to interpret.

See Patients with AAV in remission are hypercoagulable, page 2042

Personal non-commercial use only. The Journal of Rheumatology Copyright @ 2013 . All rights reserved. 
So, like most novel and interesting studies, this one is not definitive and needs to be repeated and extended. Although I advocate focusing on patients in longterm, drug-free remission - both for estimating risk of VTE and determining its mechanism - study of patients with active AAV will clearly also be of great interest ${ }^{13}$, not only to investigate mechanisms, but also to identify the best, most clinically useful markers associated with risk of VTE. More studies are needed, not only of plasma coagulability, but also on platelet function and microparticles. Unfortunately, such studies require special treatment of blood samples, so archived specimens may be of limited use. For example, Tomasson, et al found significant alterations in several plasma proteins related to platelet activation and the interaction between platelets and endothelial cells ${ }^{11}$, but these proteins also have other functions, and platelet function could not be measured directly. Similarly, my colleagues and I found that concentrations of plasminogen activator inhibitor-1 (PAI-1, an antithrombotic product of endothelial cells) in the serum of patients with active AAV were often very low ${ }^{12}$, but study of patients in that clinical trial is limited to what can be measured accurately in conventional serum or plasma.

Although it is too early to propose that ETP be used to determine whether a patient should be anticoagulated longterm - a question that arises in each of the many patients who has a VTE around the time of diagnosis or relapse - it is notable that ETP has been associated with risk of recurrent VTE in other settings, improving upon the predictive power of D-dimer and other tools for quantifying risk ${ }^{18,19}$. In addition to the obvious opportunity to determine risk factors for VTE during both active vasculitis and remission, study of prothrombotic and antithrombotic factors in AAV may help address other clinically important questions. Are persistent abnormalities predictive of disease relapse over many years, progression of renal function despite lack of evidence for recurrent glomerulonephritis ${ }^{20}$, and development of atherosclerosis and/or cardiovascular events typically associated with atherosclerosis ${ }^{21}$ ?

Studies that address these questions will need to be large, long in duration, and probably prospective, and that is a problem. However, considering that the research priority in the first 30-40 years after the description of Wegener's granulomatosis (now GPA) was finding a treatment that would keep patients alive and with functioning kidneys, it is a good problem to have. Patients in longterm, drug-free remission may now be the most under-studied category of persons with $\mathrm{AAV}$, but the existence of large numbers of such patients is - and will continue to be - a direct result of the great progress made in identifying the best and safest treatments for induction and maintenance of remission in these diseases, as informed by advances in understanding their pathophysiology.
PAUL A. MONACH, MD, $\mathrm{PhD}$,

Section of Rheumatology, Vasculitis Center, Boston University School of Medicine,

72 East Concord Street, E-533,

Boston, Massachusetts 02118, USA.

Address correspondence to Dr. Monach. E-mail: pmonach@bu.edu

\section{REFERENCES}

1. Merkel PA, Lo GH, Holbrook JT, Tibbs AK, Allen NB, Davis JC Jr, et al. Brief communication: high incidence of venous thrombotic events among patients with Wegener granulomatosis: the Wegener's Clinical Occurrence of Thrombosis (WeCLOT) Study. Ann Intern Med 2005;142:620-6.

2. Weidner S, Hafezi-Rachti S, Rupprecht HD. Thromboembolic events as a complication of antineutrophil cytoplasmic antibody-associated vasculitis. Arthritis Rheum 2006;55:146-9.

3. Allenbach Y, Seror R, Pagnoux C, Teixeira L, Guilpain P, Guillevin $\mathrm{L}$, et al. High frequency of venous thromboembolic events in Churg-Strauss syndrome, Wegener's granulomatosis and microscopic polyangiitis but not polyarteritis nodosa: a systematic retrospective study on 1130 patients. Ann Rheum Dis 2009; 68:564-7.

4. Stassen PM, Derks RP, Kallenberg CG, Stegeman CA. Venous thromboembolism in ANCA-associated vasculitis-incidence and risk factors. Rheumatology 2008;47:530-4.

5. Hansson PO, Welin L, Tibblin G, Eriksson H. Deep vein thrombosis and pulmonary embolism in the general population. "The Study of Men Born in 1913". Arch Intern Med 1997; 157:1665-70.

6. Choi HK, Rho YH, Zhu Y, Cea-Soriano L, Avina-Zubieta JA, Zhang Y. The risk of pulmonary embolism and deep vein thrombosis in rheumatoid arthritis: a UK population-based outpatient cohort study. Ann Rheum Dis 2013;72:1182-7.

7. Kim SC, Schneeweiss S, Liu J, Solomon DH. The risk of venous thromboembolism in patients with rheumatoid arthritis. Arthritis Care Res 2013;65:1600-7.

8. Bernstein CN, Blanchard JF, Houston DS, Wajda A. The incidence of deep venous thrombosis and pulmonary embolism among patients with inflammatory bowel disease: a population-based cohort study. Thromb Haemost 2001;85:430-4.

9. Sebastian JK, Voetsch B, Stone JH, Romay-Penabad Z, Lo GH, Allen NB, et al. The frequency of anticardiolipin antibodies and genetic mutations associated with hypercoagulability among patients with Wegener's granulomatosis with and without history of a thrombotic event. J Rheumatol 2007;34:2446-50.

10. Hilhorst M, Winckers K, Wilde B, van Oerle R, ten Cate H, Cohen Tervaert JW. Patients with antineutrophil cytoplasmic antibodies associated vasculitis in remission are hypercoagulable. J Rheumatol 2013;40:2042-6.

11. Tomasson G, Lavalley M, Tanriverdi K, Finkielman JD, Davis JC Jr, Hoffman GS, et al. Relationship between markers of platelet activation and inflammation with disease activity in Wegener's granulomatosis. J Rheumatol 2011;38:1048-54.

12. Monach PA, Warner RL, Tomasson G, Specks U, Stone JH, Ding L, et al. Serum proteins reflecting inflammation, injury and repair as biomarkers of disease activity in ANCA-associated vasculitis. Ann Rheum Dis 2013;72:1342-50

13. Eleftheriou D, Hong Y, Klein NJ, Brogan PA. Thromboembolic disease in systemic vasculitis is associated with enhanced microparticle-mediated thrombin generation. J Thromb Haemost 2011;9:1864-7.

14. Erdbruegger U, Grossheim M, Hertel B, Wyss K, Kirsch T, Woywodt A, et al. Diagnostic role of endothelial microparticles in vasculitis. Rheumatology 2008;47:1820-5.

15. Castoldi E, Rosing J. Thrombin generation tests. Thromb Res

Personal non-commercial use only. The Journal of Rheumatology Copyright @ 2013 . All rights reserved. 
2011;127 Suppl 3:S21-5.

16. Ballieux BE, Zondervan KT, Kievit P, Hagen EC, van Es LA, van der Woude FJ, et al. Binding of proteinase 3 and myeloperoxidase to endothelial cells: ANCA-mediated endothelial damage through ADCC? Clin Exp Immunol 1994;97:52-60.

17. Guilpain P, Servettaz A, Goulvestre C, Barrieu S, Borderie D, Chéreau C, et al. Pathogenic effects of antimyeloperoxidase antibodies in patients with microscopic polyangiitis. Arthritis Rheum 2007;56:2455-63.

18. Besser M, Baglin C, Luddington R, van Hylckama Vlieg A, Baglin T. High rate of unprovoked recurrent venous thrombosis is associated with high thrombin-generating potential in a prospective cohort study. J Thromb Haemost 2008;6:1720-5
19. Eichinger S, Hron G, Kollars M, Kyrle PA. Prediction of recurrent venous thromboembolism by endogenous thrombin potential and D-dimer. Clin Chem 2008;54:2042-8.

20. Hogan SL, Falk RJ, Chin H, Barrieu S, Borderie D, Chéreau C, et al. Predictors of relapse and treatment resistance in antineutrophil cytoplasmic antibody-associated small-vessel vasculitis. Ann Intern Med 2005;143:621-31.

21. Flossmann O, Berden A, de Groot K, Hagen C, Harper L, Heijl C, et al. Long-term patient survival in ANCA-associated vasculitis. Ann Rheum Dis 2011;70:488-94.

J Rheumatol 2013;40:1935-7; doi:10.3899/jrheum.131069 